\title{
DETERMINATION OF WATER QUALITY IN PHYSIC AND CHEMICAL USE STORET INDEX AND POLLUTION INDEX IN COASTAL WATERS DUMAI RIAU PROVINCE
}

\author{
Nur Arifin $^{1}$ · Sofyan Husein Siregar ${ }^{1} \cdot$ Syafruddin Nasution $^{1}$
}

Ringkasan The condition of good water quality is essential to support the survival of organisms that live in it. Determination of the status of water quality needs to be done as a reference in monitoring the water quality pollution.The purpose of this study to analyze and determine the status of water quality physically and chemically in the coastal waters Dumai. The method used in this research is survey method was conducted in December 2018 - April 2019 in the Coastal Water Dumai in Riau province. Sampling sites physical and chemical parameters determined by purposive sampling. Based on consideration of environmental conditions and Dumai City Regulation No. 11 In 2002, it was determined sampling consisted of four stations, with each station there are 5 sampling points were used as replicates. Determining the status of water quality using storet index and the index of pollution. Water quality measurement results About Coastal Dumai use Storet index and the pollution index shows that the co-

$\left.{ }^{1}\right)$ Marine Science Postgraduate, University of Riau E-mail: arifinik013@gmail.com astal waters of Dumai categorized as Heavy Polluted waters.

Keywords Dumai, Water Status, Heavy

Polluted, Purposive Sampling

Received : 24 Agustus 2019

Accepted :23 September 2019

\section{PENDAHULUAN}

Kota Dumai merupakan salah satu dari 12 kabupaten / kota di Provinsi Riau. Ditinjau dari letak geografis, Kota Dumai terletak antara $101^{0} 23^{\prime} 37^{\prime \prime}-101^{0}$ $8^{\prime} 13^{\prime \prime}$ Bujur Timur dan $1^{0} 23^{\prime} 23^{\prime \prime}-1^{0} 24^{\prime} 23^{\prime \prime}$ Lintang Utara dengan luas wilayah 1.727,38 $\mathrm{km}^{2}$. Salah satu persoalan lingkungan Kota Dumai adalah adanya potensi pencemaran pada perairan pesisir yang ditimbulkan dari berbagai kegiatan pemanfaatan ruang/wilayah. Masalah pencemaran ini disebabkan aktivitas manusia seperti, pengembangan perkotaan dan industri, penebangan hutan serta limbah permukiman yang masuk ke perairan melalui aliran sungai. Pesatnya pengembangan perkotaan dan industri telah meningkatkan jumlah limbah terutama limbah cair yang sulit dikontrol (Fransisca, 2011). 
Pada dasarnya bahan pencemar yang mencemari perairan dapat dikelompokkan menjadi bahan pencemar organik dan bahan pencemar anorganik. Kegiatan perindustrian, seperti 3 industri yang turut serta memajukan Kota Dumai. Industri tersebut diantaranya PT. CPI (Chevron Pacific Indonesia) yang bergerak mayoritas dalam bidang pertambangan dan ekspor minyak dan gas bumi, kemudian PT. Pertamina yang bergerak dalam bidang pengolahan dan pendistribusian minyak dan gas bumi dalam negeri serta industri pengolahan minyak sawit (CPO) PT. BKR (Bukit Kapur Reksa) yang berada di sepanjang pesisir Kota Dumai dan pelabuhan internasinal.

Kegiatan tersebut memberikan dampak negatif terhadap perairan pesisir Kota Dumai, seperti tekanan yang tinggi terhadap kualitas perairan dan dapat mendegradasi ekosistem perairan (Badrun, 2008). Limbah yang mengendap ke dasar perairan Selat Rupat berdampak luas sampai pada kawasan pesisir Kota Dumai (Larasati et al., 2015). Salah satu indikator terjadinya degradasi terhadap kualitas perairan dapat dilihat dari adanya perubahan parameter kualitas air. (Rudiyanti, 2009).

Beberapa penelitian terdahulu tentang studi kondisi fisika dan kimia perairan di sekitar Dumai Marine Station Selat Rupat dan Selat Malaka Dumai (Amin, 1996). Penelitian pencemaran juga dilakukan oleh Amin et al. (2005) tentang konsentrasi logam berat $(\mathrm{Cd}, \mathrm{Cu}$, $\mathrm{Pb}$ dan $\mathrm{Zn}$ ) di Telescopium telescopium di perairan Pantai Dumai untuk menentukan pencemaran perairan Kota Dumai. Selain itu, penelitian juga dilakuan oleh Rasmiati et al. (2017) mengenai analisis kandungan bahan organik

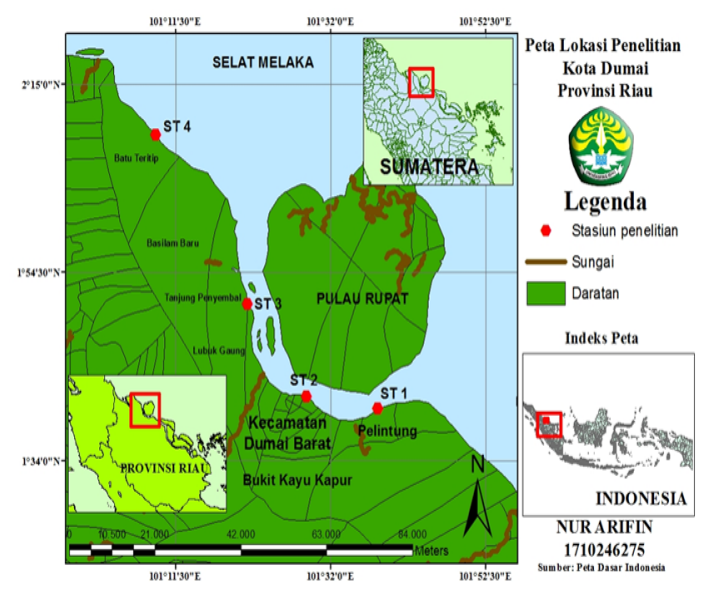

Gambar 1 Lokasi Pengambilan Sampel

total dan kelimpahan fitoplankton di perairan muara Sungai Dumai.

Berdasarkan uraian pada latar belakang di atas, peneliti perlu menganalisis kualitas perairan secara fisika dan kimia. Menganalisis status mutu perairan pesisir Kota Dumai dengan menggunaka metode storet dan indeks pencemaran perairan. Tujuan dan manfaat pada penelitian ini ialah Menganalisis kualitas perairan secara fisik dan kimia di perairan pesisir Kota Dumai dan manfaat dari hasil penelitian ini adalah dapat mengetahui kondisi kualitas perairan pesisir Kota Dumai baik secara fisika maua pun secara kimia.

\section{MATERI DAN METODE}

Penelitian ini dilaksanakan pada bulan Desember 2018 - April 2019 di Perairan Pesisir Kota Dumai Provinsi Riau. Sedangkan analisis parameter fisik dan kimia dilakukan di Laboratorium Oseanografi Kimia Jurusan Ilmu Kelautan Fakultas Perikanan dan Kelautan Universitas Riau.

Indeks storet digunakan untuk menentukan status mutu air, berdasarkan Per- 
aturan Menteri Negara Lingkungan Hidup No. 51 Tahun 2004 tentang Pengelolaan Kualitas Air dan Pengendalian Pencemaran Air. Cara menentukan status mutu air adalah dengan menggunakan sistem nilai dengan mengklasifikasikan mutu air dalam 4 kelas yaitu

1. Kelas A : baik sekali, skor $=0=$ memenuhi baku mutu

2. Kelas $\mathrm{B}$ : baik, skor $=-1 \mathrm{~s} / \mathrm{d}-10=$ tercemar ringan

3. Kelas $\mathrm{C}$ : sedang, skor $=-11 \mathrm{~s} / \mathrm{d}-30$ $=$ tercemar sedang

4. Kelas D : buruk, skor $\geq 31=$ tercemar berat.

Pengelolaan kualitas air berdasarkan Indeks Pencemaran (IP) dapat digunakan untuk mengambil keputusan agar dapat menilai kualitas badan air di hitung dengan persamaan sebagai Fakhrunnisa (2015):

$p i j=\sqrt{\frac{\sqrt{\frac{(c i)}{l i j} R^{2}+\frac{(c i)}{l i j} M^{2}}}{2}}$

Adapun evaluasi terhadap nilai PI (Pollution Index) sesuai Keputusan Menteri Negara Lingkungan Hidup No.115 Tahun 2003 adalah sebagai berikut:

- $0 \leq \mathrm{Pij} \leq 1,0$, Memenuhi Baku Mutu;

- 1,0 $\leq \mathrm{Pij} \leq 5,0$, Cemar Ringan;

- 5,0<Pij $\leq 10$, Cemar Sedang;

- Pij > 10, Cemar Berat.

Pengukuran kualitas perairan dilakukan secara in situ dan ex situ yang terdiri dari parameter fisik yang meliputi suhu, kecepatan arus, kecerahan, kekeruhan, fraksi sedimen dan parameter kimia yang terdiri dari salinitas, derajat keasaman, bahan organik, COD, $\mathrm{BOD}_{5}$, nitrat dan fosfat.

\section{HASIL DAN PEMBAHASAN}

Kota Dumai merupakan salah satu dari 12 kabupaten/ kota di Propinsi Riau. Ditinjau dari letak geografis, Kota Dumai terletak pada posisi antara 1010 23' 37" - 1010 80' 13" Bujur Timur dan 10 23'23" - 10 24'23" Lintang Utara dengan luas wilayah $1.727,38 \mathrm{~km} 2$. Kota Dumai memiliki 16 sungai besar dan kecil dengan total panjang keseluruhan $222 \mathrm{~km}$. Jumlah penduduk sebesar 253.803 jiwa yang dikelola di lima (5) kecamatan dan 33 kelurahan, dengan batas-batas wilayah sebagai berikut: sebelah utara berbatasan dengan Selat Rupat. Sebelah timur berbatasan dengan Kecamatan Bandar Laksamana Kabupaten Bengkalis. Sebelah selatan berbatasan dengan Kecamatan Bathin Solapan dan Kecamatan Bukit Batu Kabupaten Bengkalis. Sebelah barat berbatasan dengan Kecamatan Tanah Putih dan Kecamatan Sinaboi Kabupaten Rokan Hilir (BPS, 2018).

Parameter fisika dan kimia air merupakan faktor yang sangat menentukan bagi kehidupan organisme perairan. Daya dukung parameter ini akan berpengaruh secara langsung maupun tidak langsung terhadap siklus hidup diatom epipelik, terutama dalam hal pertumbuhan dan reproduksi.

Parameter fisika air yang diamati meliputi : suhu, kecerahan, kekeruhan dan kecepatan arus serta fraksi sedimen. Hasil pengukuran parameter fisika air pada setiap stasiun di perairan sekitar pesisir Kota Dumai terdapat pada Tabel 1.

Berdasarkan hasil penelitian (Tabel 1) memperlihatkan bahwa kisaran rata-rata suhu perairan Pesisir Kota Dumai 30,56 $-33,08{ }^{\circ} \mathrm{C}$. Secara umum hasil pengu- 
Tabel 1 Hasil Rata-Rata Pengukuran Parameter Fisika Air Sekitar Pesisir Perairan Kota Dumai

\begin{tabular}{ccccc}
\hline \multirow{2}{*}{ Parameter } & \multicolumn{4}{c}{ Stasiun Penelitian } \\
\cline { 2 - 5 } & 1 & 2 & 3 & 4 \\
\hline Suhu (C) & $33,08 \pm 1,9$ & $32,34 \pm 0,9$ & $30,56 \pm 0,6$ & $31,90 \pm 0,4$ \\
Kecerahan (cm) & $30,80 \pm 2,8$ & $49,30 \pm 30,1$ & $77,80 \pm 8,2$ & $134,7 \pm 1,0$ \\
Kec. Arus (m/detik) & $0,14 \pm 0,032$ & $0,07 \pm 0,028$ & $0,08 \pm 0,02$ & $0,13 \pm 0,05$ \\
Kekeruhan (NTU) & $171,7 \pm 85,2$ & $143,0 \pm 74$ & $259 \pm 69,8$ & $20,80 \pm 20,8$ \\
Fraksi Sedimen (MZ) & $5.04 \pm 0,1$ & $6.35 \pm 1,1$ & $5,66 \pm 0,2$ & $5,44 \pm 0,1$ \\
\hline
\end{tabular}

kuran suhu masih layak untuk pertumbuhan dan perkembangan Diatom epipelik. Hal ini didukung oleh penjelasan Junda et al. (2013), diatom epipelik akan tumbuh dengan baik pada kisaran suhu berturut-turut dari $20 \pm 30$ ${ }^{\circ} \mathrm{C}-30 \pm 35{ }^{\circ} \mathrm{C}$, dikarenakan penyerapan panas matahari yang masuk ke badan perairan oleh partikel-partikel tersuspensi maupun terlarut, baik yang berasal dari limbah industri maupun domestik. Hal ini sejalan dengan hasil pengukuran Kekeruhan di perairan sekitar pesisir Kota Dumai dengan rata-rata hasil pengukuran 20,08 - 259 NTU. Berdasarkan KEP MENLH No. 51 Tahun 2004 nilai tersebut telah melewati standar baku mutu perairan untuk kehidupan biota.

Hasil analisis partikel sedimen dari 4 stasiun penelitian didapatkan ukuran partikel sedimen dengan nilai phi 5,04 6,35 . Nilai phi partikel butiran sedimen tertinggi yaitu terdapat di stasiun 2 (merupakan lumpur halus) dan nilai phi partikel butiran sedimen terendah terdapat pada stasiun 1, 3 dan 4 merupakan lumpur kasar. Secara keseluruhan fraksi sedimen di Perairan Pesisir Kota Dumai merupakan partikel halus berbentuk lumpur yang merupakan substrat yang banyak mengandung bahan organik. Partikel sedimen yang kecil dapat mengendap jauh dari lokasi pelepasan partikel tersebut dan dapat menjebak bahan organik.
Rata-rata nilai kecerahan di perairan sekitar pesisir Kota Dumai diperoleh nilai berkisar 30,80 - 134,70 cm. Berdasarkan hasil pengukuran, kecerahan pada stasiun 1 dan 2 menunjukkan nilai yang lebih rendah jika dibandingkan stasiun 3 dan 4 . Hal ini dapat dimengerti sebab letak stasiun ini lebih dekat dengan pelabuhan dan daerah permukiman dengan turbulensi perairan yang lebih kuat dan partikel-partikel sedimen dari dasar perairan teraduk ke permukaan perairan. Kecerahan di bawah 30 $\mathrm{cm}$ mengindikasikan terjadinya blooming alga, sedangkan kecerahan lebih dari $45 \mathrm{~cm}$ mengindikasikan rendahnya kelimpahan diatom (Hidayat, 2017).

Kecepatan arus adalah faktor penting di perairan mengalir dan dapat mempengaruhi jenis-jenis diatom yang hidup di perairan. Kecepatan arus yang besar dapat mengurangi jenis organisme yang tinggal sehingga hanya jenisjenis yang melekat saja yang bertahan terhadap arus. Perairan dengan kecepatan arus 0,2 $-1 \mathrm{~m} /$ detik didominasi oleh diatom epipelik dan epifitik. Nilai rata-rata hasil pengukuran kecepatan arus di perairan Pesisir Kota Dumai 0,08-0,14 m/detik. Kecepatan arus tersebut tergolong sangat lemah hingga sedang. Menurut Maharani (2007), arus yang kurang dari $0,1 \mathrm{~m} /$ detik termasuk kecepatan arus yang sangat lemah, sedangkan kecepatan arus sebesar 0,1 - 1 $\mathrm{m} /$ detik tergolong kecepatan arus yang 
sedang, kecepatan arus $>1 \mathrm{~m} / \mathrm{dtk}$ tergolong kecepatan arus yang kuat.

Parameter kimia air yang diukur dalam penelitian ini antara lain : salinitas, $\mathrm{pH}$, oksigen terlarut (DO), BOD (Biological Oxigen Demand), COD (Chemycal Oxygen Demand), TOM (Total Organic Matter), fosfat dan nitrat. Data parameter kimia air selama penelitian tersaji pada Tabel 2 .

Rata-rata nilai salinitas sekitar pesisir Perairan Kota Dumai berkisar antara 27,80 - 29,42 \%o. Nilai yang terukur masih berada dalam kisaran nilai salinitas ratarata untuk perairan laut Indonesia. Menurut Nontji (2008) bahwa salinitas di perairan laut berkisar antara $24-35$ $\%$. Demikian pula yang dijelaskan oleh Patty (2013), salinitas di perairan Indonesia pada umumnya berkisar antara $30-35 \%$. Berdasarkan hasil pengukuran, kisaran salinitas dianggap masih layak untuk pertumbuhan dan perkembangan fitoplankton. Hal ini sesuai dengan pernyataan Rahmawati et al. (2013)bahwa salinitas mempengaruhi produksi fitoplankton, struktur komunitas fitoplankton dapat mengalami perubahan sejalan dengan perubahan salinitas. Variasi salinitas mempengaruhi laju fotosintesis terutama di daerah estuari khususnya pada diatom yang hanya bisa bertahan pada batas-batas salinitas yang kecil (stenohaline). Salinitas yang sesuai bagi fitoplankton adalah di atas 20 ppt. Salinitas seperti itu menyebabkan fitoplankton dapat bertahan hidup dan memperbanyak diri serta aktif melaksanakan proses fotosintesis.

Hasil pengukuran $\mathrm{pH}$ selama penelitian diperoleh nilai rata-rata pada kisaran yang masih tergolong baik untuk perairan yaitu nilai $\mathrm{pH}$ perairan $8,18-8,5$.
Nilai pH yang diperoleh menunjukkan kesuburan perairan sekitar pesisir Kota Dumai masih tergolong produktif untuk pertumbuhan diatom dan belum membatasi laju pertumbuhannya. Berdasarkan KEP MENLH No. 51 Tahun 2004, nilai $\mathrm{pH}$ optimal untuk kehidupan diatom epipelik yang merupakan salah satu kelas dari fitoplankton yaitu $7-8,5$.

Karbon organik pada lokasi penelitian bervariasi dengan nilai TOM (Total Organic Matter) di Sedimen 3,68 - 5,35 $\%$. Kandungan karbon organik tertinggi terdapat pada stasiun 2 dan terendah stasiun 4. Kandungan bahan organik tersebut termasuk dalam klasifikasi tanah mineral dengan kandungan bahan organik tinggi (Supono, 2008). Kandungan bahan organik yang tinggi akan menyebabkan tingginya kebutuhan oksigen (DO) untuk menguraikan bahan tersebut baik itu secara biologi maupun secara kimiawi.

BOD menggambarkan jumlah oksigen yang dibutuhkan oleh mikroba aerob untuk mengoksidasi bahan organik menjadi karbondioksida dan air. Kadar BOD berbeda-beda tiap lokasi berdasarkan kandungan bahan organik dan aktivitas mikroba yang menguraikannya. Ratarata nilai BOD pada lokasi penelitian adalah BOD Perairan $8-17,33 \mathrm{mg} / \mathrm{l}$ sedangkan nilai COD Perairan berkisar 27,93 - 33,60 mg/l, untuk lebih jelasnya dapat dilihat pada Gambar 2.

BOD merupakan kebutuhan oksigen oleh mikroorganisme di perairan untuk mendegradasi unsur-unsur sederhana hingga senyawa komplek yang berasal dari limbah domestik yang dibuang atau secara alamiah terdapat di dalam perairan. Estimasi BOD mempunyai sasaran untuk mengevaluasi beban polutan akibat limbah domestik dan mengesti- 
Tabel 2 Hasil rata-rata pengukuran parameter kimia air sekitar Pesisir Perairan Kota Dumai

\begin{tabular}{ccccc}
\hline \multirow{2}{*}{ Parameter Kimia } & \multicolumn{4}{c}{ Stasiun penelitian } \\
\cline { 2 - 5 } & 1 & 2 & $29,4 \pm 3,90$ & 4 \\
\hline Salinitas (\%o) & $28,4 \pm 2,90$ & $26,7 \pm 2,90$ & $8,50 \pm 0,21$ & $27,8 \pm 1,90$ \\
pH & $8,18 \pm 0,16$ & $8,50 \pm 0,17$ & $17,3 \pm 2,50$ & $8,46 \pm 0,14$ \\
BOD5 (mg/l) & $12,7 \pm 2,50$ & $14,3 \pm 1,70$ & $33,6 \pm 12,1$ & $8,00 \pm 1,60$ \\
COD (mg/l) & $27,9 \pm 13,8$ & $31,7 \pm 9,50$ & $5,10 \pm 0,78$ & $33,6 \pm 7,90$ \\
TOM $(\%)$ & $5,01 \pm 0,71$ & $5,35 \pm 1,74$ & $3,68 \pm 1,09$ \\
\hline
\end{tabular}

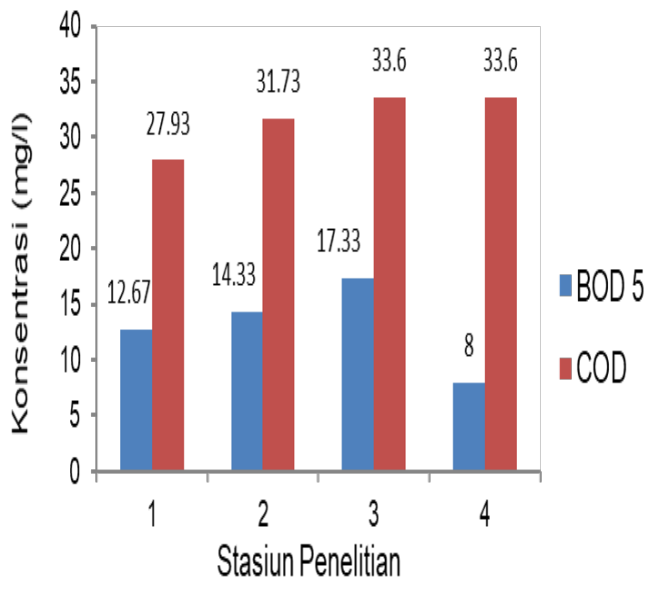

Gambar 2 Hasil pengukuran BOD5 dan COD di sekitar Perairan Pesisir Kota Dumai

masi pengaruhnya terhadap lingkungan. Mikroorganisme dapat menghabiskan oksigen terlarut dan selama proses oksidasi tersebut ikan dapat mati karena kekurangan oksigen. Selain itu keadaan bisa menjadi anaerobik dan dapat menimbulkan bau busuk pada air tersebut. Nilai baku mutu kebutuhan oksigen biokimia adalah $10 \mathrm{mg} / \mathrm{L}$ untuk biota laut (KEP MENLH No. 51 tahun 2004). Tingginya nilai $\mathrm{BOD}_{5}$ yang sudah melebihi ambang baku mutu pada stasiun 1, 2 dan 3 menyebabkan mikroba menjadi aktif dan menguraikan bahan organik yang tinggi pada stasiun 1 , 2 dan 3 (Tabel 3 TOM $>5 \%$ ) yang secara biologis menjadi senyawa asamasam organik. Penguraian ini terjadi secara aerob dan anaerob. Penguraian secara anaerob menimbulkan gas $\mathrm{CH}_{4}$, $\mathrm{NH}_{3}$ dan $\mathrm{H}_{2} \mathrm{~S}$ yang berbau busuk (Djarwati et al., 2000). Tingginya kandung- an BOD5 yang terdapat pada kawasan pelabuhan, permukiman dan industri pada stasiun 1, 2 dan 3 yaitu karena disebabkan tingginya kandungan limbah organik yang berasal dari daratan. Komoditi utama ekspor melalui Pelabuhan Dumai adalah minyak sawit dan minyak RBD yang merupakan output dari industri pengolahan CPO di Kawasan Pelabuhan Dumai. Sedangkan komoditi utama impor melalui Pelabuhan Dumai adalah pupuk curah dimana umumnya kegiatan tersebut menghasilkan polutan minyak dan bahan organik.

Chemical Oxygen Demand (COD) diartikan jumlah total oksigen yang dibutuhkan untuk mengoksidasi bahan organik secara kimiawi, baik yang dapat didegradasi secara biologis maupun yang sukar didegradasikan secara biologis menjadi karbondioksida dan air. Hasil pengukuran COD di Perairan pesisir Kota Dumai berkisar 27,93 - 33,60 mg/l. Nilai COD pada setiap stasiun penelitian sudah melewati baku mutu lingkungan. Nilai COD yang terlalu tinggi dapat menghambat pertumbuhan organisme akuatik. Berdasarkan KEPMEN LH No. 51/2004 bahwa nilai COD yang baik pada perairan dan masih mendukung kehidupan organisme dan salah satunya adalah diatom epipelik yaitu 25 $\mathrm{mg} / \mathrm{l}$.

Tingginya nilai COD di perairain Pesisir Kota Dumai disebabkan banyak- 
nya masukan bahan pencemar berupa bahan organik maupun anorganik dan tingginya aktifitas pelabuhan dan domestik sekitar permukiman dan kegiatan perindustrian, seperti 3 industri yang turut serta memajukan Kota Dumai. Industri tersebut diantaranya PT. CPI yang bergerak mayoritas dalam bidang pertambangan dan ekspor minyak dan gas bumi, kemudian PT. Pertamina yang bergerak dalam bidang pengolahan dan pendistribusian minyak dan gas bumi dalam negeri serta industri pengolahan minyak sawit (CPO) PT. BKR yang berada di sepanjang pesisir Kota Dumai. Dimana limbah tersebut masuk ke perairan secara konstan dan terus menerus selama kegiatan tersebut berlangsung.

Tingginya aktifitas antropogenik yang dijelaskan di atas mengakibatkan kondisi pesisir Kota Dumai banyak menerima pasokan limbah organik dan tumpahan minyak maupun limbah anorganik. Hal ini dijelaskan oleh Zahidin (2008), bahwa bahan organik dapat berasal dari alam maupun aktivitas rumah tangga dan industri. Hal ini diperkuat oleh Umiatun et al. (2017), bahwa bahan pencemar organik dapat diuraikan oleh organisme secara kimia. Bahan tersebut secara terus menerus masuk ke perairan dan diendapkan di dasar perairan. Hal ini dinyatakan oleh Pertamina and PPLH (2002), bahwa gerakan polutan minyak yang masuk ke Selat Rupat hanya mengalami pergerakan bolak-balik dan mengendap tanpa mampu keluar mencapai Selat Malaka.

Nitrat merupakan indikator adanya keberadaan nutrien di perairan dalam bentuk yang dapat langsung dimanfaatkan oleh tumbuhan laut seperti diatom epipelik dalam proses fotosintetis. Untuk
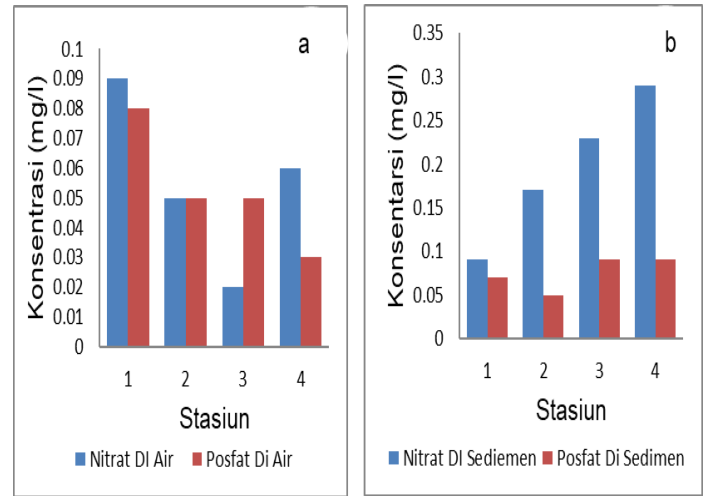

Gambar 3 Rata-Rata Konsentasi Nitrat dan Fosfat di Air (a) dan Sedimen (b)

lebih jelasnya dapat di lihat pada Tabel 3.

Konsentrasi nitrat dan fosfat di laut sangat penting dalam menunjang keutuhan ekosistem perairan. Hal itu terjadi karena nitrat dan fosfat merupakan unsur yang digunakan dalam proses fotosintesis dan merupakan unsur yang digunakan untuk pertumbuhan diatom epipelik. Kadar nitrat dan fosfat yang banyak dalam suatu perairan dapat dikatakan bagus atau subur. Untuk lebih jelasnya konsentrasi nitrat dan fosfat pada sedimen dan air dapat dilhat pada Gambar 3.

Berdasarkan Gambar 3, kosentrasi nitrat dan fosfat di air (Gambar 3a) lebih rendah dari pada kosentrasi nitrat dan fosfat di sedimen (Gambar 3b). Hal ini dikarenankan sumber bahan organik dari daratan diendapkan di sedimen dasar perairan sehingga terjadi penumpukan bahan organik pada sedimen. Sedimen yang berasal dari daratan merupakan sedimen lumpur yang berpartikel halus mengandung bahan organik yang tinggi dan diendapkan ke dasar perairan. Berdasarkan hasil pengukuran, fosfat di air 0,03 - 0,08 mg/l dan konsentrasi nitrat di air 0,02 - 0,09 mg/l. sedangkan konsetasi nitrat di sedimen 0,09- 
Tabel 3 Konsentrasi Nitrat dan Fosfat pada Sedimen dan Air di Sekitar Pesisir Perairan Kota Dumai

\begin{tabular}{ccccc}
\hline Stasiun & Nitrat (mg/l) (Sedimen) & Fosfat (mg/l) (Sedimen) & Nitrat (mg/l) (Air) & Fosfat (mg/l) (Air) \\
\hline 1 & $0,09 \pm 0,01$ & $0,07 \pm 0,02$ & $0,09 \pm 0,01$ & $0,08 \pm 0,02$ \\
2 & $0,17 \pm 0,05$ & $0,05 \pm 0,01$ & $0,05 \pm 0,01$ & $0,05 \pm 0,02$ \\
3 & $0,23 \pm 0,11$ & $0,09 \pm 0,03$ & $0,02 \pm 0,01$ & $0,05 \pm 0,01$ \\
4 & $0,29 \pm 0,08$ & $0,09 \pm 0,04$ & $0,06 \pm 0,01$ & $0,03 \pm 0,01$ \\
\hline
\end{tabular}

$0,29 \mathrm{mg} / \mathrm{l}$ dan konsentarsi fosfat di sedimen $0,05-0,09 \mathrm{mg} / \mathrm{l}$. Nilai tertinggi untuk konsentasi fosfat di sedimen terdapat pada stasiun $4(0,29 \mathrm{mg} / \mathrm{l})$. Tingginya konsentasi fosfat disebabkan karena stasiun 4 merupakan daerah alami yang kondisi ekosistem mangrovenya masih dalam kondisi baik serta merupakan daerah sirkulasi perairan dan daerah muara sungai kecil yang ada di daerah tersebut sehingga limbah domestik yang berasal dari permukiman warga menjadi faktor utama tingginya konsentasi fosfat pada lokasi ini. Hal ini dijelaskan oleh Effendi (2003)bahwa sumber antropogenik fosfat di perairan adalah limbah industri dan domestik, yaitu fosfat yang berasal dari deterjen. Limpasan dari daerah pertanian yang menggunakan pupuk juga memberikan konstribusi yang cukup besar bagi keberadaan fosfat di perairan. Umumnya kandungan fosfat total di perairan alami tidak lebih dari $0,1 \mathrm{mg} / \mathrm{l}$ kecuali pada perairan penerima limbah rumah tangga dan dari daerah pertanian yang mengalami pemupukan.

Hasil pengukuran konsentrasi fosfat yang optimum untuk pertumbuhan diatom berkisar 0,09-1,80 mg/l sedangkan minimum nitrat yang dapat diserap oleh diatom adalah berkisar $0,001-0,007$ $\mathrm{mg} / \mathrm{l}$. Jika kurang dari nilai tersebut maka fosfat dan nitrat dikategorikan sebagai faktor pembatas di perairan ((Permatasari et al., 2016). Hal ini dikarenakan nitrat dan fosfat merupakan bahan organik sebagai unsur hara yang di-
Tabel 4 Kualitas perairan sekitar Pesisir Kota Dumai berdasarkan skor Storet

\begin{tabular}{lccc}
\hline No & Parameter & Sub Parameter & Skor \\
\hline 1 & & suhu & $-2,25$ \\
2 & Fisika & kecerahan & -5 \\
3 & & kekeruhan & $-4,75$ \\
4 & $\mathrm{pH}$ & $-1,5$ \\
5 & & $\mathrm{BOD}$ & 0 \\
6 & & $\mathrm{COD}$ & -10 \\
7 & Kimia & Fosfat & -10 \\
8 & & Nitrat & -10 \\
& & & $-43,5$ \\
\hline
\end{tabular}

butuhkan oleh diatom untuk proses metabolisme, pertumbuhan dan perkembangan (Aini et al., 2017).

Indeks Storet merupakan salah satu instrumen untuk mengukur kualitas ketercemaran suatu badan perairan dengan menggunakan data perbandingan antara data kualitas air dengan baku mutu air yang disesuaikan dengan peruntukannya. Hasil perhitungan storet berdasarkan parameter fisika dan kimia dapat dilihat pada Tabel 4. Nilai skor yang didapatkan dijumlahkan. Untuk lebih jelasnya dapat dilihat pada Tabel 4 .

Hasil pengukuran kualitas perairan sekitar Pesisir Kota Dumai menurut Indeks Storet menunjukkan bahwa skoring Indeks Storet -43,5. Berdasarkan klasifikasi Indeks Storet, skoring ini bermakna bahwa sekitar perairan Pesisir Kota Dumai terkategori Kelas D dengan skor $\geq-31$ diklasifikasikan sebagai perairan tercemar berat.

Penentuan status mutu air pada sekitar perairan Pesisir Kota Dumai didasarkan atas metode Indeks Pencemaran. Suatu perairan dikatakan tercemar 
Tabel 5 Nilai Indeks Pencemaran perairan Pesisir Kota Dumai

\begin{tabular}{cccc}
\hline No & Parameter & Sub Parameter & Indeks Pencemaran (IP) \\
\hline 1 & & Suhu Air & 0,75 \\
2 & Fisika & Kecerahan & 0,16 \\
3 & & Kekeruhan & 6,19 \\
4 & & pH & 0,76 \\
5 & & BOD 5 & 0,55 \\
6 & \multirow{2}{*}{ Kimia } & COD & 1,12 \\
7 & & Oksigen Terlarut & 0,69 \\
8 & & Fosfat & 2,96 \\
9 & & Nitrat & 3,94 \\
& & & 17,10 \\
\hline
\end{tabular}

apabila tidak dapat digunakan sesuai dengan peruntukaannya secara normal. Hasil analisis nilai Indeks Pencemaran pada lokasi penelitian ini selengkapnya disajikan pada Tabel 5.

Berdasarkan hasil perhitungan Indeks Pencemaran (IP) pada Tabel 6 maka dapat diketahui bahwa perairan Pesisir Kota Dumai sudah dalam keadaan tercemar berat dengan total skor IP 17,10 (IP $>10,0$ dengan status perairan tercemar berat atau heavily polluted). Hal ini disebabkan karena pengaruh dari wilayah pesisir atau daratan, sehingga dampak dari hasil aktifitas masyarakat di daratan sangat tinggi. Hal ini dapat ditunjukkan dengan konsentrasi dari beberapa parameter lingkungan seperti bahan organik, fosfat dan nitrat memiliki konsentrasi yang lebih besar dibandingkan dengan baku mutu perairan.

\section{SIMPULAN}

Hasil pengukuran kualitas perairan sekitar Pesisir Kota Dumai menggunakan Indeks Storet dan Indeks Pencemaran menunjukkan bahwa perairan Pesisir Kota Dumai terkategori sebagai perairan tercemar berat. Sehingga pemerintah perlu meningkatkan program pengelolaan pencemaran Kota Dumai yang statusnya telah tercemar berat. Peningkatan yang harus dilakukan diantaranya perencanaan, pengawasan dan penegakan peraturan bagi setiap para pelaku usaha dan perlu adanya pola kerjasama dan koordinasi antara pemerintah. masyarakat, serta LSM yang bergerak dibidang lingkungan dalam mengelola perairan Kota Dumai.

\section{Pustaka}

Aini, Z., Mulyadi, A., and Amin, B. (2017). Analisis komposisi diatom epipelik sebagai bioindikator pencemaran perairan pantai kota dumai provinsi riau. Kutubkhanah, 18(1):7-18.

Amin, B., Ismail, A., Kamarudin, M., Arshad, A., and Yap, C. (2005). Heavy metals (cd, cu, pb and zn) concentrations in telescopium telescopium from dumai coastal waters, indonesia. Pertanika Journal of Tropical Agricultural Science, 28(1):33.

Badrun, Y. (2008). Analisis kualitas perairan selat rupat sekitar aktivitas industri minyak bumi kota dumai. Jurnal Ilmu Lingkungan, 2(01).

BPS (2018). Dumai dalam angka. Technical report, BPS Dumai.

Djarwati, D., Sartamtomo, S., and Sukani, S. (2000). Pemanfaatan energi hasil pengolahan limbah cair industri tahu. Jurnal Kimia Sains dan Aplikasi, 3(2):66-70.

Effendi, H. (2003). Telaah kualitas air, bagi pengelolaan sumber daya dan lingkungan perairan. Kanisius.

Fakhrunnisa, A. (2015). Analisis tingkat pencemaran air laut pada kawasan sekitar pelabuhan paotere. Universitas Hasanuddin, Makassar. 
Fransisca, A. (2011). Tingkat pencemaran perairan ditinjau dari pemanfaatan ruang di wilayah pesisir kota cilegon. Journal of Regional and $\mathrm{Ci}$ ty Planning, 22(2):145-160.

Hidayat, T. (2017). Kelimpahan dan struktur komunitas fitoplankton pada daerah yang di reklamasi pantai seruni kabupaten bantaeng.

Junda, M., Hijriah, and Hala, Y. (2013). Identifikasi perifiton sebagai penentu kualitas air pada tambak ikan nila (oreochromis niloticus). Jurnal Bionature, 14(1):16-24.

Larasati, C. E., Kawaroe, M., and Prartono, T. (2015). Karakteristik diatom di selat rupat riau. Indonesian Journal of Marine Sciences/Ilmu Kelautan, 20(4).

Maharani, H. W. (2007). Kajian kualitas perairan di pantai kota Bandar Lampung berdasarkan komunitas hewan makrobenthos. $\mathrm{PhD}$ thesis, program Pascasarjana Universitas Diponegoro.

Nontji, A. (2008). Plankton laut. Yayasan Obor Indonesia.

Patty, S. I. (2013). Distribusi suhu, salinitas dan oksigen terlarut di perairan kema, sulawesi utara. Jurnal Ilmiah Planax, 1(3).

Permatasari, R. D., Djuwito, D., and Irwani, I. (2016). Pengaruh kandungan nitrat dan fosfat terhadap kelimpahan diatom di muara sungai wulan, demak. Management of Aquatic Resources Journal, 5(4):224232.

Pertamina and PPLH, U. (2002). Sedimentasi dan dispersi limbah cair pertamina. Technical report, Pusat Penelitian Lingkungan Hidup Universitas Riau.

Rahmawati, I., Purnomo, P. W., and Hendrarto, B. (2013). Fluktuasi bahan organik dan sebaran nutrien serta kelimpahan fitoplankton dan klorofil-a di muara sungai sayung demak. Management of Aquatic Resources Journal, 3(1):27-36.

Rasmiati, E., Nedi, S., and Amin, B. (2017). Analysis of total organic matter and fitoplankton abundance in the dumai river estuary waters of riau province. Jurnal Online Mahasiswa Fakultas Perikanan dan Ilmu Kelautan Universitas Riau, 4(2):111.

Rudiyanti, S. (2009). Kualitas perairan sungai banger pekalongan berdasarkan indikator biologis. SAINTEK PERIKANAN: Indonesian Journal of Fisheries Science and Technology, 4(2):46-52.

Supono, S. (2008). Analisis diatom epipelic sebagai indikator kualitas lingkungan tambak untuk budidaya udang. PhD thesis, Program Pasca Sarjana Universitas Diponegoro.

Umiatun, S., Carmudi, C., and Christiani, C. (2017). Hubungan antara kandungan silika dengan kelimpahan diatom benthik di sepanjang sungai pelus kabupaten banyumas. Scripta Biologica, 4(1).

Zahidin, M. (2008). Kajian kualitas air di muara sungai pekalongan Ditinjau dari indeks keanekaragaman Makrobenthos dan indeks saprobitas Plankton. PhD thesis, Program Pascasarjana Universitas Diponegoro. 